\title{
IDŐJÁRÁS
}

Quarterly Journal of the Hungarian Meteorological Service

Vol. 124, No. 2, April-June, 2020, pp. 253-276

\section{Hungarian regions and cities towards an adaptive future - analysis of climate change strategies on different spatial levels}

\author{
Mária Szalmáné Csete * and Attila Buzási \\ Department of Environmental Economics \\ Budapest University of Technology and Economics \\ Magyar tudósok krt. 2., H-1117, Budapest, Hungary \\ *Corresponding Author e-mail: csete@eik.bme.hu
}

(Manuscript received in final form January 23, 2020)

\begin{abstract}
Nowadays, urban areas are increasingly identified as strategic fields of climate change-related actions. Climate change is an increasingly complex challenge for these territories. Tackling climate change, moreover, in a sustainable way, is a priority in the European Union, which has set several ambitious short- and long-term mitigation, adaptation, and sustainability targets. It is a central issue of how society can respond to the climate emergency that is affected by and depends on the vertical and horizontal interrelations among different stakeholders, organizations, governance actors, etc., and their activities. Countries, regions, counties, and cities around the world react by developing climate strategies. The operationalization of the high-level political agreements and discourses is uncertain, and the policies in practice should also be evaluated on regional and city levels, just as the milestones of related strategic planning processes fostering local adaptive capacity. According to regional and urban governance, it is pivotal addressing not only mitigation but adaptation issues to be able to foster sustainable regional development, also considering the UN Sustainable Development Goals (SDGs) specified in the Agenda 2030. Adaptation to climate change is increasingly becoming a priority for policy action. It also has high relevance to find the synergic interrelations towards an adaptive future. This paper evaluates the recent changes in Hungarian regional and urban planning in relation to climate policy approach and reports a state of adaptation oriented spatial planning on NUTS-3 (Nomenclature of Territorial Units for Statistics) and LAU-1 (Local Administrative Units) levels. The results are based on the collection of all relevant climate change-related strategic documents on these levels in Hungary and on the analysis of specific information. There is a lack of knowledge related to the comprehensive adaptation policy and planning on regional and local levels in Hungary. The results of the evaluation show the state-of-art knowledge related to possible adaptation pathways and the various engagement level for climate policy approach on different spatial levels in Hungary. In the case of the examined research area, the development of more mitigation oriented planning documents and low level of adaptation measures and monitoring process management tools is seen as critical.
\end{abstract}

Key-words: climate strategies, SECAP-Sustainable Energy and Climate Action Plan, adaptation pathways, sustainable regional development, NUTS-3, LAU-1, Hungary 


\section{Introduction}

Reducing adverse effects of climate change by taking into consideration both mitigation and adaption activities are at the forefront in current policies (European Commission, 2011; UNFCCC, 2015) and international scientific interests (Sharifi and Yamagata, 2016; Mendizabal et al., 2018). Dated back to Agenda 21 proposals from the Rio Earth Summit in 1992, various spatial levels are urged by the UN at the end of the Climate Summit in $2019^{1}$ to develop and to perform concrete actions and implementations in the field of climate change.

Hungary is facing numerous challenges regarding changing climatic patterns (Bartholy et al., 2007, 2009; Szépszó, 2008; Krüzselyi et al., 2011; Torma et al., 2011; Pongrácz et al., 2013, 2014; Kis et al., 2017); therefore, it can be stated that climate change adaptation is a crucial part of the long-term sustainability in the center of the Carpathian Basin. Based on the review of the international literature, numerous studies regarding climate adaptation in a Hungarian context can be found concerning various relevant sectors, such as tourism (Csete et al., 2013; Kovács and Unger, 2014; Csete and Szécsi, 2015; Kovács et al., 2017); natural assets (Malatinszky et al., 2013; Mezösi et al., 2013; Hlásny et al., 2014; Mezösi et al., 2014; Szabó et al., 2016); human health (Páldy et al., 2005; Páldy and Bobvos, 2010; Solymosi et al., 2010; Törö et al., 2010; Bobvos et al., 2015); agriculture (Jolánkai and Birkás, 2007; Zemankovics, 2012; Gaál et al., 2014; Li et al., 2017a, 2018); water management (Werners et al., 2009; Lóczy, 2010; Blanka et al., 2013; Mezösi et al., 2013; Rojas et al., 2013); energy supply and demand from different perspectives (Bartholy et al., 2003; Tánczos and Török, 2007; Szlávik and Csete, 2012; Hrabovszky-Horváth et al., 2013); transport (Szendrö et al., 2014); or urban development issues (Csete and Horváth, 2012; Czakó, 2013; Buzási, 2014; Csete and Buzási, 2016; Li et al., 2017b; Kántor et al., 2018). Apart from the relative richness of literature with regards to adaptation issues, highly heterogeneous knowledge can be found if we try to analyze climate adaptation activities on a different spatial level. On NUTS-1 level (countries), among other things, Berkhout et al. (2015), Heidrich et al. (2016), and Pietrapertosa et al. (2018) aimed at comparing climate change policies and plans, however, the regional and local scale regarding analysis of climate change strategies and other related thematic development plans is almost completely lacking with an emphasis on adaptation issues in Hungary. It is worth mentioning that some studies have been dealing with a comparison of local climate plans across Europe (Heidrich et al., 2013; Reckien et al., 2014, 2015, 2018); however, the selection of analyzed Hungarian cities is based on their total population; therefore, a small pool of Hungarian settlements have been involved and evaluated. Cities or more precisely, local level play a crucial role in climate

\footnotetext{
${ }^{1}$ https://www.un.org/en/climatechange/un-climate-summit-2019.shtml
} 
adaptation activities (Rosenzweig et al., 2010; Hunt and Watkiss, 2011; MillardBall, 2013; Wamsler et al., 2013; Ürge-Vorsatz et al., 2018), but NUTS-3 level is often out of scope of analysis of climate change plans from both mitigation and adaptation point of view, while counties are highly important actors on climate adaptation issues in Hungary. During the previous years, numerous Hungarian cities and counties were engaged in developing their climate strategies to reduce GHG emissions and to be prepared concerning changing climatic patterns and the adverse of climate change. Based on previously stated reasons, the present study aims at analyzing climate strategies of Hungarian counties and county seats by paying particular attention to adaptation issues. Relationships between planning procedures and outcomes of the selected strategies are analyzed; therefore, all documents were evaluated by applying a detailed survey that can grasp the most important strengths and weaknesses of the planning processes. In the following chapters, firstly, the applied methodology is introduced, then the main results grouped by counties and cities are revealed; finally, conclusions and potential opportunities are highlighted.

\section{Methodology}

There is an increasing demand on both the science and policy sides to deliver some performance evaluation related to climate planning on different spatial levels. It is pivotal to be able to see the current status of climate oriented urban planning, especially when the focus is on adaptation. Spatial adaptation actions, interventions, and options can be examined through the systematic evaluation and detailed analysis of Hungarian counties and county seats. Considering county (NUTS-3) and county seat (LAU-1) level, there is a lack of climate planning assessment in Hungary. However, in this country, it is traditionally a well-functioning and effective territorial level. Thus, the engagement of the examined areas towards the climate planning approach and notable adaptation can play a pivotal role in further sustainable regional development perspectives.

Fig. 1 shows the territorial scope of the evaluation, namely the 19 Hungarian counties and county seats plus the capital. Budapest, as the capital of Hungary, compared to the 19 counties and county seats, has special rights according to law. Due to the significant contribution to GDP and the dominant percentage of the Hungarian population, it was examined together with the group of counties in this evaluation process. 


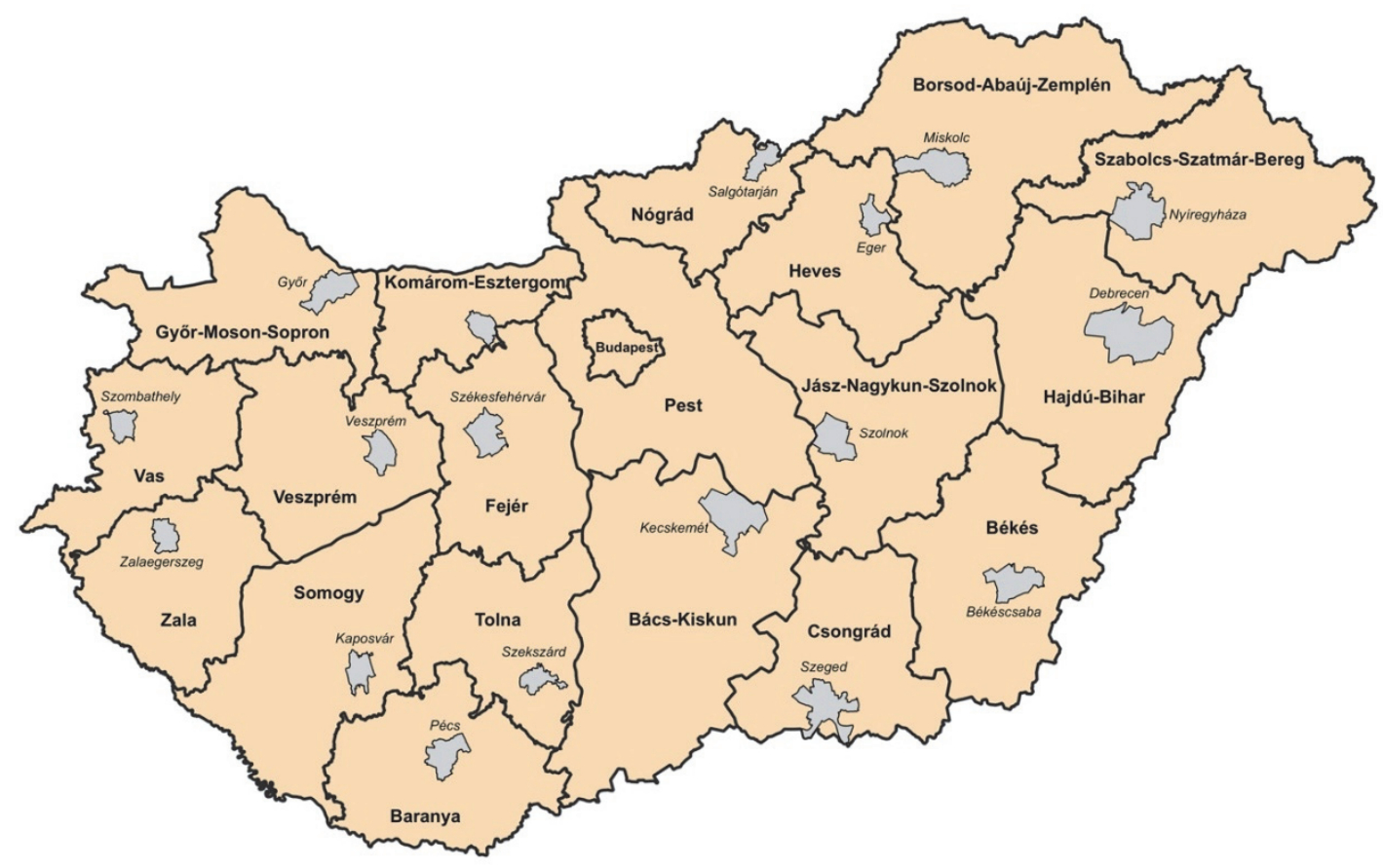

Fig. 1. Examined area: The 19 Hungarian counties (including the capital) and county seats.

Urban areas are expected to become increasingly crucial actors both in mitigation and adaptation issues, which can be an especially revise assumption in Europe, where the $74 \%{ }^{2}$ of the population lives in these areas. The municipalities on different spatial levels are usually more engaged towards climate-friendly and sustainable ways of developments in those cases and places, where they have the possibility to receive financial and expert support from central governments (Eckersley et al., 2018; Bellinson and Chu, 2019; Kern, 2019). Regarding the international scientific literature, several research results can be found mainly dealing with general aspects, EU (Castán Broto, 2017; Mendizabal et al., 2018; Reckien et al., 2018, 2019) or country-specific (Berkhout et al., 2015; Heidrich et al., 2016; Pietrapertosa et al., 2018), territorial scope aiming attention at climate change in urban planning processes. According to the review of the above mentioned relevant research papers and methodologies, the main steps of recent evaluation is based on the following:

1. Identification of the existing types of climate change-related strategic and planning documents on the relevant spatial levels (counties and the capital, county seats);

2. Examination of the availability of relevant climate change-related strategic and planning documents;

\footnotetext{
${ }^{2}$ https://www.statista.com/statistics/270860/urbanuzation-by-continent/
} 
3. Selection of the relevant climate change-related strategic and planning documents;

4. Adaptation oriented questionnaire development for the in-depth analysis considering the main research questions;

5. Online collecting form development and conduct the in-depth analysis;

6. Evaluation of the research results.

On county, capital and county seat level identified relevant climate strategies and other planning documents types belong to climate strategies or Sustainable Energy and Climate Action Plans (SECAPs). Related to countylevel climate strategies, common methodology and guideline development were supported by the central government as well as the elaboration of the documents. All of the identified document was available online. In cases where both types of document are existing, the climate strategy was prioritized. The main research question emphasized the recent knowledge and the state of adaptation planning on different spatial levels in Hungary. The main examined topics according to adaptation oriented questionnaire have the following structure:

A) General information:

- County/county seat name

- Weblink of the document

- Year of document development

- Type of document

- Existence of document history

B) Content related information:

- Spatial characteristics

- General climate related outlook (global, regional, local)

- Area-specific impacts based on identified local characteristics

- Vulnerable social groups

- Adaptation aims related information

- Sectors related to the adaptation aims

- Impacts related to the adaptation aims

- Number of adaptation aims

- Types of adaptation oriented actions, interventions

- Monitoring phase 
- Existence of monitoring phase

○ Features of existing monitoring phase

- Document development and general layout

○ Stakeholder involvement

○ Proportion of adaptation compared to mitigation

An online collecting form was developed and used for the feasibility of the in-depth analysis. The data collection was conducted from the beginning of September to the end of October 2019.

\section{Results}

In the present chapter, results regarding the detailed analysis of counties and county seats will be presented in that order. Budapest is involved in the group of counties, due to its specific rights, size, and importance with regards to both mitigation and adaptation issues. The structure of the visualization is almost the same for both groups; however, it can be seen that there are some differences between the presentation of the results since some questions are more relevant and provide more specific outcomes in the case of cities rather than counties.

The first question was focusing on the date of approval concerning climate change strategies of counties. Since the Hungarian government decided to support the development of climate change strategies on NUTS-3 level through the Environment and Energy Operational Programme in 2016, consequently majority of strategies was developed and approved in 2018 (16 of 20), only Heves County, Győr-Moson-Sopron County, Bács-Kiskun County, and Vas County released their documents in the year of 2017. All of the analyzed documents on the county level are stand-alone climate strategies in terms of their type; moreover, the vast majority of them are the first attempt due to the lack of climate strategies on the NUTS-3 level in Hungary. 18 of 20 strategies have a general outlook on climate change with regards to global or local impacts, risks, and other related issues. In the climate strategy of Békés and Fejér counties, this thematic outlook is completely lacking.

Similar to the previously presented results, highlights of local-specific impacts of climate change concerning different time-scales are a well-documented part of the selected strategies, since 17 of them defined observed changes from the past, 19 of 20 have dedicated chapter regarding present impacts, and 19 of them paid attention to future projections (see Fig. 2). By focusing on the existing differences across strategies, it is worth mentioning that in the strategy of Békés County had nothing to do with past and present impacts, Baranya County Climate Strategy is not detailing future risks; moreover, the analysis of observed changes lacks in case of both Jász-Nagykun-Szolnok and Komárom-Esztergom counties. 


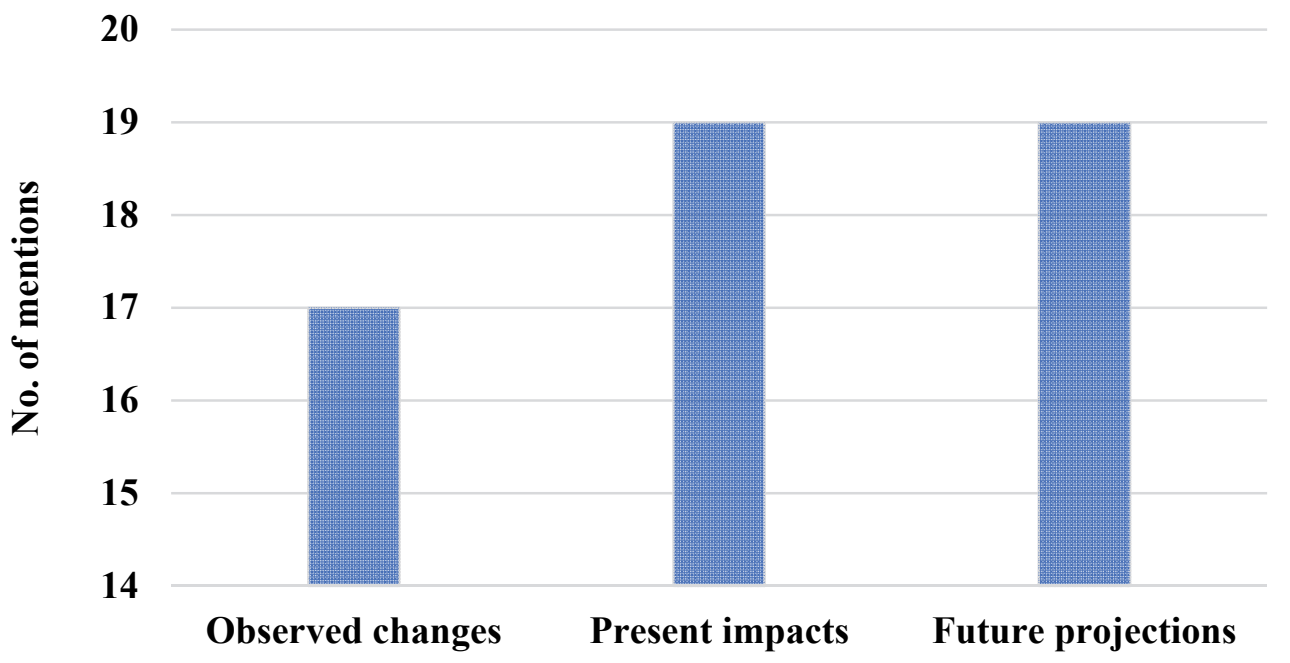

Fig. 2. Absolute number of mentions of local-specific impacts in climate strategies on county level.

Besides the collection of different impacts via a long time-scale, defined climate-related risks and actions were also revealed by analyzing the selected strategies. Based on the previously cited regional climate models, increasing temperature and changing precipitation patterns are the two significant impacts of climate change in the Carpathian Basin. Apart from them, it can be stated that other impacts can also be distinguished, such as waterlogging, flood, drought, extreme storms, etc., that affect counties and other spatial levels in a different way. Fig. 3 represents the total number of mentions of different climate-related impacts in climate strategies of county level. Increasing temperature, drought, and storms were mentioned in every stand-alone document, while changing precipitation patterns have been defined in the case of 16 strategies. Risks regarding flood and waterlogging are less emphasized due to geographical differences of counties.

After collecting and analyzing climate-related impacts in selected climate strategies, detailed evaluation regarding distinguished actions has been performed to reveal potential lacks and opportunities to improve the quality of climate strategies by bridging the gap between defined impacts and related actions. Table 1 shows this relationship as mentioned earlier between impacts and defined actions in the case of every county and by using a three-step approach. Green cells refer to the best scenario, where a given climate impact is distinguished in the analyzed document; moreover, at least one dedicated action (related to the impact) is also developed. The light yellow color means that actions can be found in the given strategy without a previously defined impact. Dark orange cells represent the worst case when a given impact is previously distinguished and marked as an important challenge for the county; however, there is no developed action related to that significant risk. Finally, N/D means 
there is neither impact(s) nor action(s) in the analyzed strategy. It can be seen that increasing temperature and drought are the two impacts, where all county documents defined them and assigned related actions as well. In the case of storms, some strategies distinguished as associated climate impacts, but related actions have not been developed (Baranya, Csongrád, Györ-Moson-Sopron, and Jász-Nagykun-Szolnok counties). Flood and waterlogging are the two most heterogeneous impacts due to their strong local-specific and geographic-related features. In the climate strategy of Hajdú-Bihar County, Nógrád County, and Vas County, dark orange cells refer to the lack of actions besides the defined challenges regarding flood, while waterlogging is a relevant adverse effect of climate change in Hajdú-Bihar, Nógrád, Somogy, Szabolcs-Szatmár-Bereg, and Zala counties, related actions have not been found in their documents.

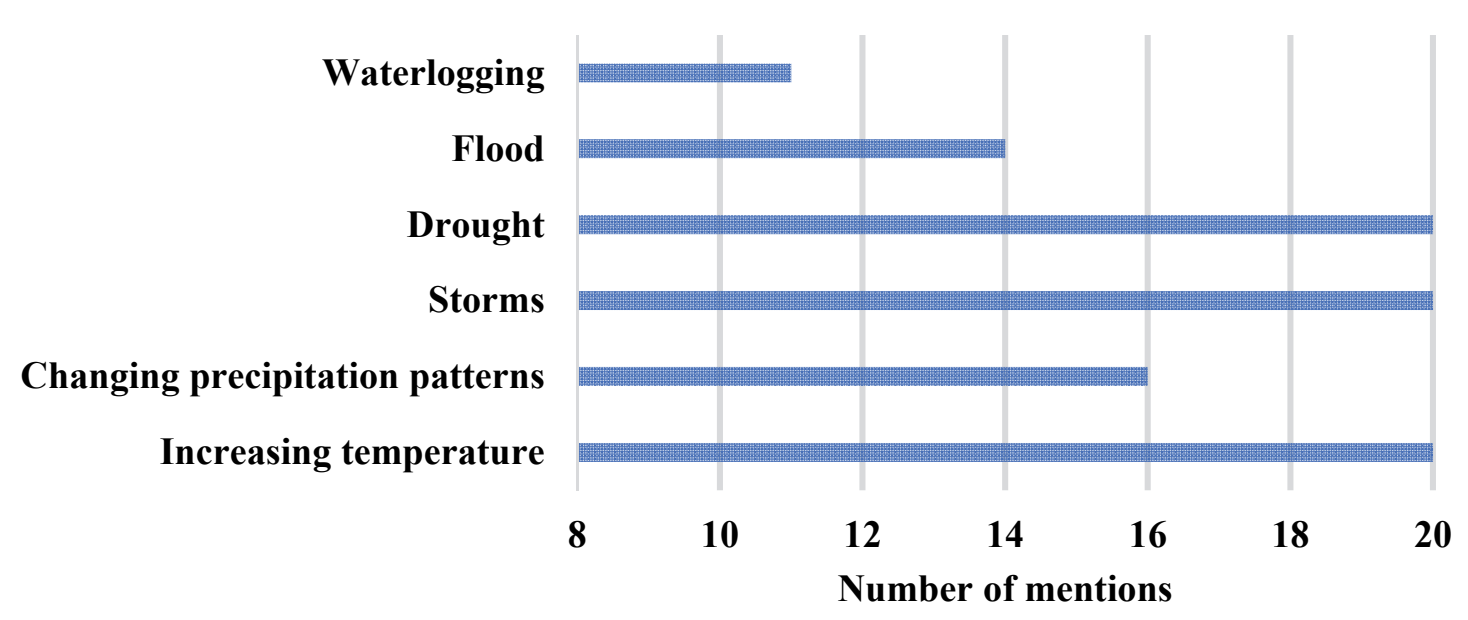

Fig. 3. Total number of mentions of climate-related impacts.

Considering adaptation issues through document analysis, distinguishing vulnerable social groups with regards to changing climate patterns and related weather extremes is a crucial component of effective climate strategies. For that purpose, Fig. 4. shows the total number of mentions of different vulnerable groups appearing in the selected and analyzed strategies on the county level. It can be stated that infants, elderly people, and people with cardiovascular disease are well involved in the documents as the most vulnerable social groups to heatwaves. People with disabilities have been mentioned in 8 of 20 documents; however, it is a much better inclusion compared to outdoor workers and poor people with only one mention. It cannot be found such a stand-alone document that took into consideration all of these vulnerable social groups: the majority of the strategies was focusing on the previously mentioned first three groups. Risks regarding outdoor workers appear in the climate strategy of Budapest, and poor 
people were distinguished as a vulnerable societal dimension in the strategy of Tolna County. It is worth mentioning and emphasizing that the climate strategy of Vas County specified only one vulnerable social group (poor people) in the document.

Table 1. Pairs of climate-related impacts and dedicated actions

\begin{tabular}{|c|c|c|c|c|c|c|}
\hline & $\begin{array}{l}\text { Increasing } \\
\text { temperature }\end{array}$ & $\begin{array}{c}\text { Changing } \\
\text { precip. } \\
\text { patterns } \\
\end{array}$ & Storms & Drought & Flood & Waterlogging \\
\hline $\begin{array}{l}\text { Bács-Kiskun } \\
\text { County }\end{array}$ & & N/D & & & N/D & \\
\hline Baranya County & & & & & N/D & $\mathrm{N} / \mathrm{D}$ \\
\hline Békés County & & & $\mathrm{N} / \mathrm{D}$ & & & $\mathrm{N} / \mathrm{D}$ \\
\hline \multicolumn{7}{|l|}{$\begin{array}{l}\text { Borsod-Abaúj- } \\
\text { Zemplén County } \\
\end{array}$} \\
\hline Budapest & & & & & & N/D \\
\hline Csongrád County & & & & & & $\mathrm{N} / \mathrm{D}$ \\
\hline Fejér County & & & & & N/D & $\mathrm{N} / \mathrm{D}$ \\
\hline \multicolumn{7}{|l|}{$\begin{array}{l}\text { Győr-Moson- } \\
\text { Sopron County }\end{array}$} \\
\hline $\begin{array}{l}\text { Hajdú-Bihar } \\
\text { County }\end{array}$ & & $\mathrm{N} / \mathrm{D}$ & & & & \\
\hline \multicolumn{7}{|l|}{ Heves County } \\
\hline \multicolumn{7}{|l|}{$\begin{array}{l}\text { Jász-Nagykun- } \\
\text { Szolnok County }\end{array}$} \\
\hline $\begin{array}{l}\text { Komárom- } \\
\text { Esztergom County }\end{array}$ & & & & & & $\mathrm{N} / \mathrm{D}$ \\
\hline \multicolumn{7}{|l|}{ Nógrád County } \\
\hline \multicolumn{7}{|l|}{ Pest County } \\
\hline \multicolumn{7}{|l|}{ Somogy County } \\
\hline \multicolumn{7}{|l|}{$\begin{array}{l}\text { Szabolcs-Szatmár- } \\
\text { Bereg County }\end{array}$} \\
\hline \multicolumn{7}{|l|}{ Tolna County } \\
\hline Vas County & & & & & & $\mathrm{N} / \mathrm{D}$ \\
\hline Veszprém County & & & & & N/D & $\mathrm{N} / \mathrm{D}$ \\
\hline Zala County & & & & & & \\
\hline
\end{tabular}




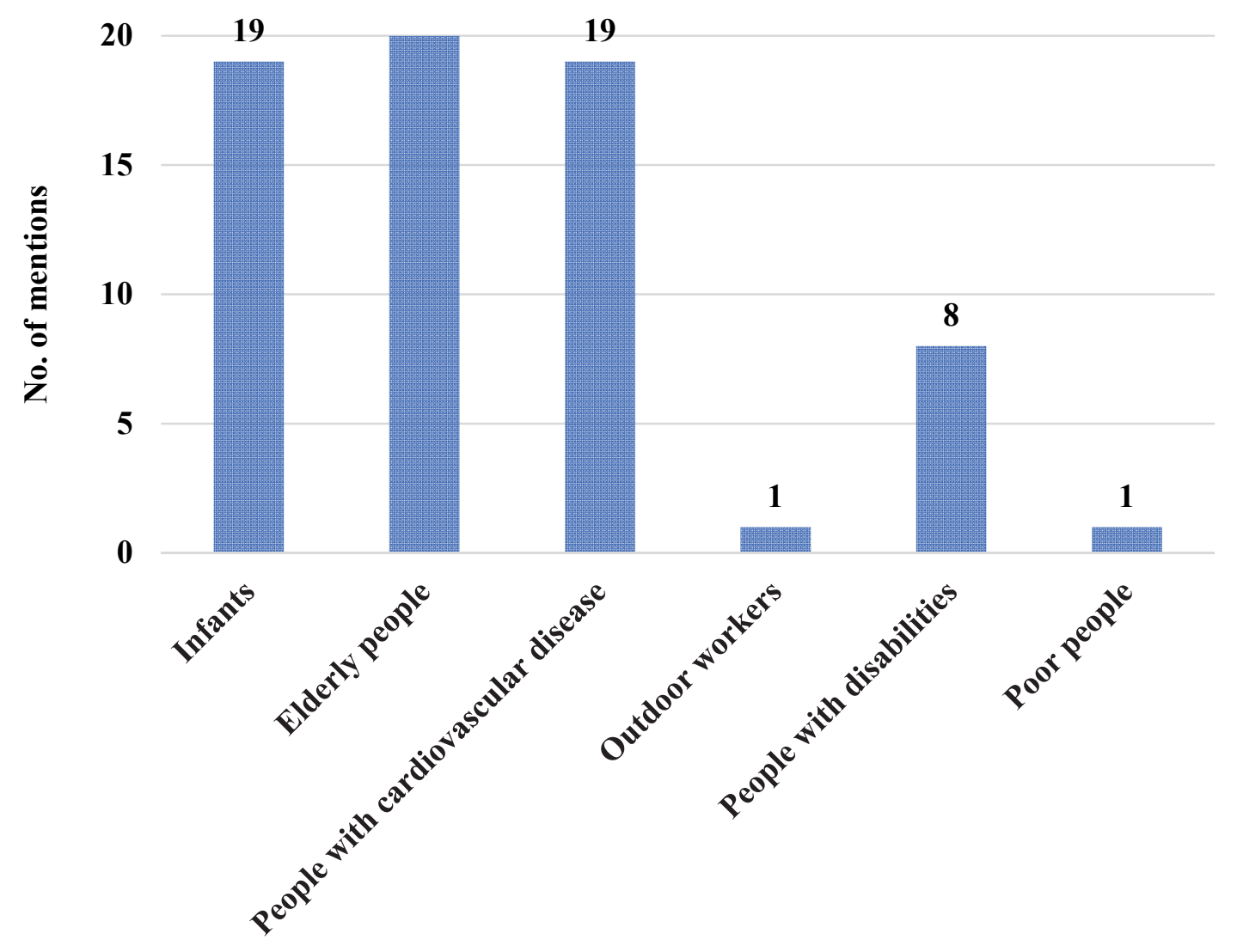

Fig. 4. Total number of mentions of vulnerable social groups.

Well-structured aims focusing on both existing and projected adverse effects of climate change are cornerstones of effective climate strategies. Based on this assumption, the following two sections are introducing the primary outcomes of our survey focusing on the aims regarding analyzed strategies. Firstly, Fig. 5 represents the total number of mentions regarding whether a given sector is defined and distinguished through the adaptation aims in a given strategy or not. Based on the evaluation of the results, it can be stated that two main groups of sectors are appearing: in the first, pool, water management, agriculture, tourism, health, urban planning, and natural values are all well emphasized with between 17 and 20 mentions, respectively. However, forest fire, industry, transport, and energy supply are mentioned much less by the county-level climate strategies. It is worth emphasizing that the natural and social-based differences between counties entail different structures of aims and related sectors, but this gap, as mentioned earlier, between the two groups shall be emphasized. 


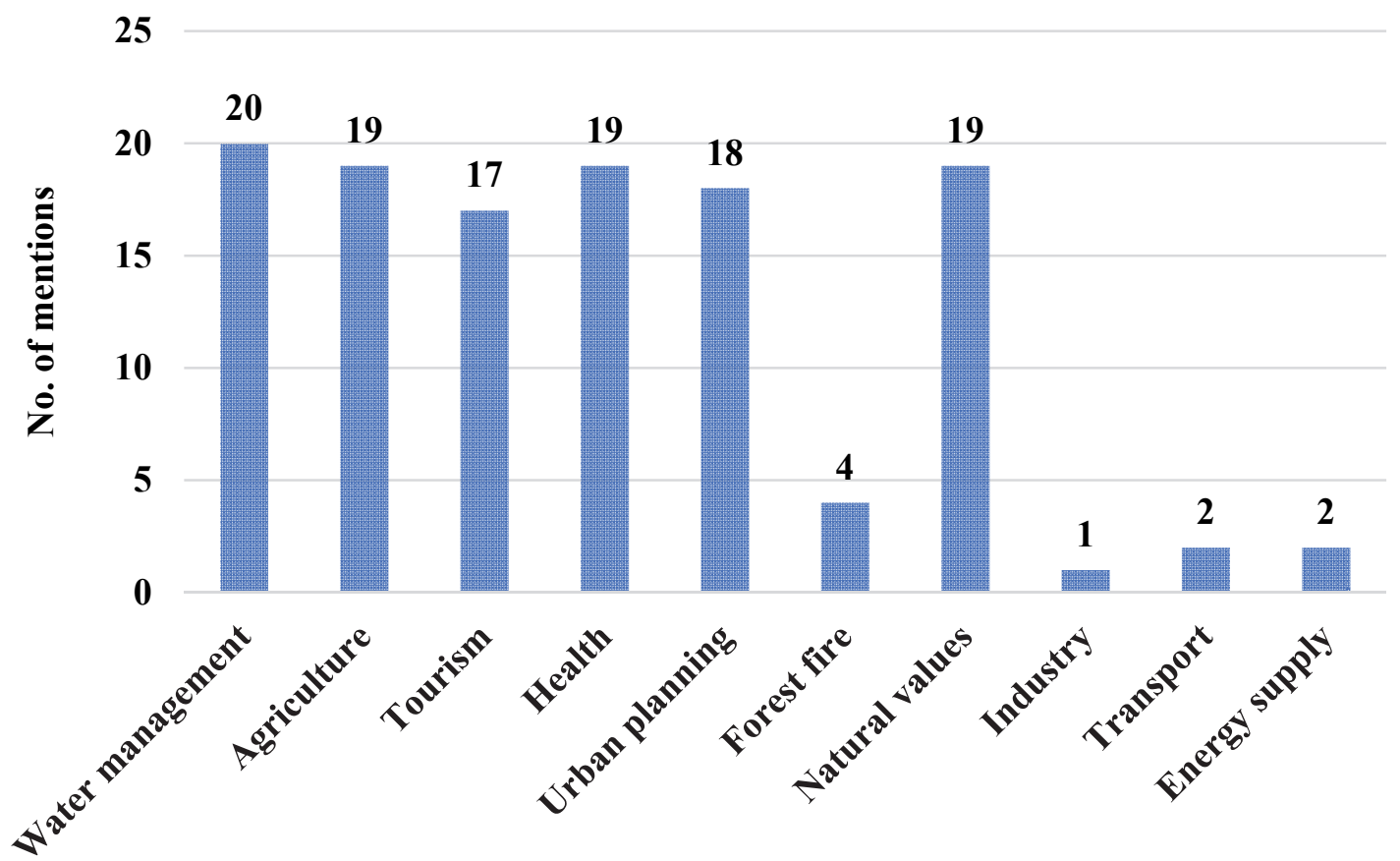

Fig. 5. Total number of mentions of sectors among the aims of climate strategies.

Developed and distinguished adaptation actions are crucial in the implementation phase and efficiently contribute to reducing the overall vulnerability of counties by covering as many critical issues as they can. Naturally, it cannot be declared that more adaptation actions entail less vulnerability in a linear relationship. However, complete with the previously introduced results, slightly more transparent conclusions can be made regarding the adaptation-oriented aim structure of the climate strategies of Hungarian counties. Therefore, Fig. 6 aims at visualizing the total number of adaptation actions grouped by counties, respectively. Fejér and Komárom-Esztergom counties have the highest number of adaptation actions (with 25 and 19 actions), while the Baranya County Climate Strategy defined only five interventions. The average number of adaptation actions is approximately 11 .

Besides the unquestionable importance of aims and their structure, evaluation of adaptation oriented interventions contributes to analyzing the county-level climate strategies more transparently. For that reason, our survey has a dedicated question about the main characteristics of interventions based on their types. The majority of climate strategies include technical solutions, policy tools, and awareness-raising projects, whit much less attention to education, financial tools, and research and development $(\mathrm{R}+\mathrm{D})$ actions. The presence of financial tools among adaptation actions is the least, only 5 of 20 climate strategies (Budapest, Nógrád County, Szabolcs-Szatmár-Bereg County, Veszprém County, and Zala County) have mentioned them as potential tools for improving adaptive capacity within the administrative borders. 


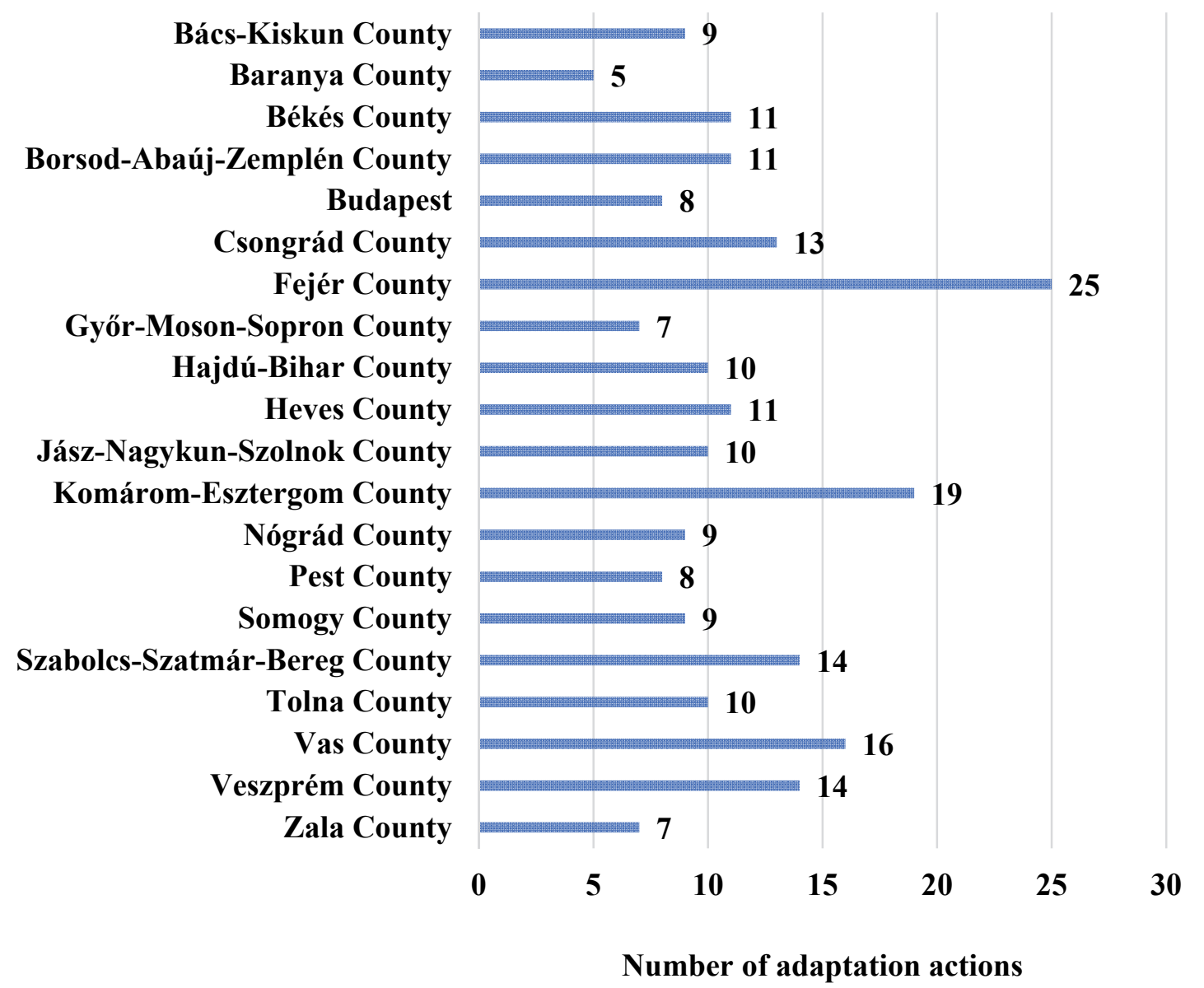

Fig. 6. Total number of adaptation actions in the analyzed climate strategies.

Monitoring phases in development strategies ensure the effectiveness of these documents by controlling and evaluating the processes which are needed to enhance climate adaptivity. In the case of Hungarian county-level climate change strategies, Jász-Nagykun-Szolnok and Vas counties' documents had nothing to do with the monitoring phase. On the opposite side, the vast majority of analyzed strategies have a comprehensive set of indicators, time frame, and budget allocation to enhance the effectiveness of their interventions. However, it shall be emphasized that preference order and responsibility issues have not been involved in the monitoring chapters at all. In a close context of the monitoring phase, the developed strategy-analysis survey has taken into consideration stakeholder inclusiveness during the preparation phase of the strategies. Only the Békés County Climate Strategy has not mentioned the list of involved stakeholders during the planning procedure, while the majority of climate strategies listed numerous NGOs, universities, public authorities, companies and other economic and social actors who were active contributors to the development of the county-level climate change strategies. 
Finally, the last evaluated aspects regarding the strategies are the length of mitigation and adaptation-oriented pages. It is worth repeatedly emphasizing that the total length of adaptation-centered content is not closely related to its effectiveness, but an overview can be made by using this information about the strategies. Fig. 7 summarizes the relative share of mitigation and adaptationrelated contents in the face of the total length of the strategies in descending order. It means that the relatively lengthiest adaptation part of climate strategies can be found in the case of Vas County with $39 \%$, while the shortest adaptationoriented sections can be read in the Jász-Nagykun-Szolnok County Climate Change Strategy. It shall be emphasized that the majority of strategies have paid more attention to adaptation issues (except Szabolcs-Szatmár-Bereg County and Somogy County), which is related to a clear trend of shifting the main intervention points from mitigation actions to adaptation ones in the international policy-making processes. The role of industry, transport, and energy supply concerning improvement of adaptive capacity is clear, however, these sectors were barely specified in the county-level strategies.

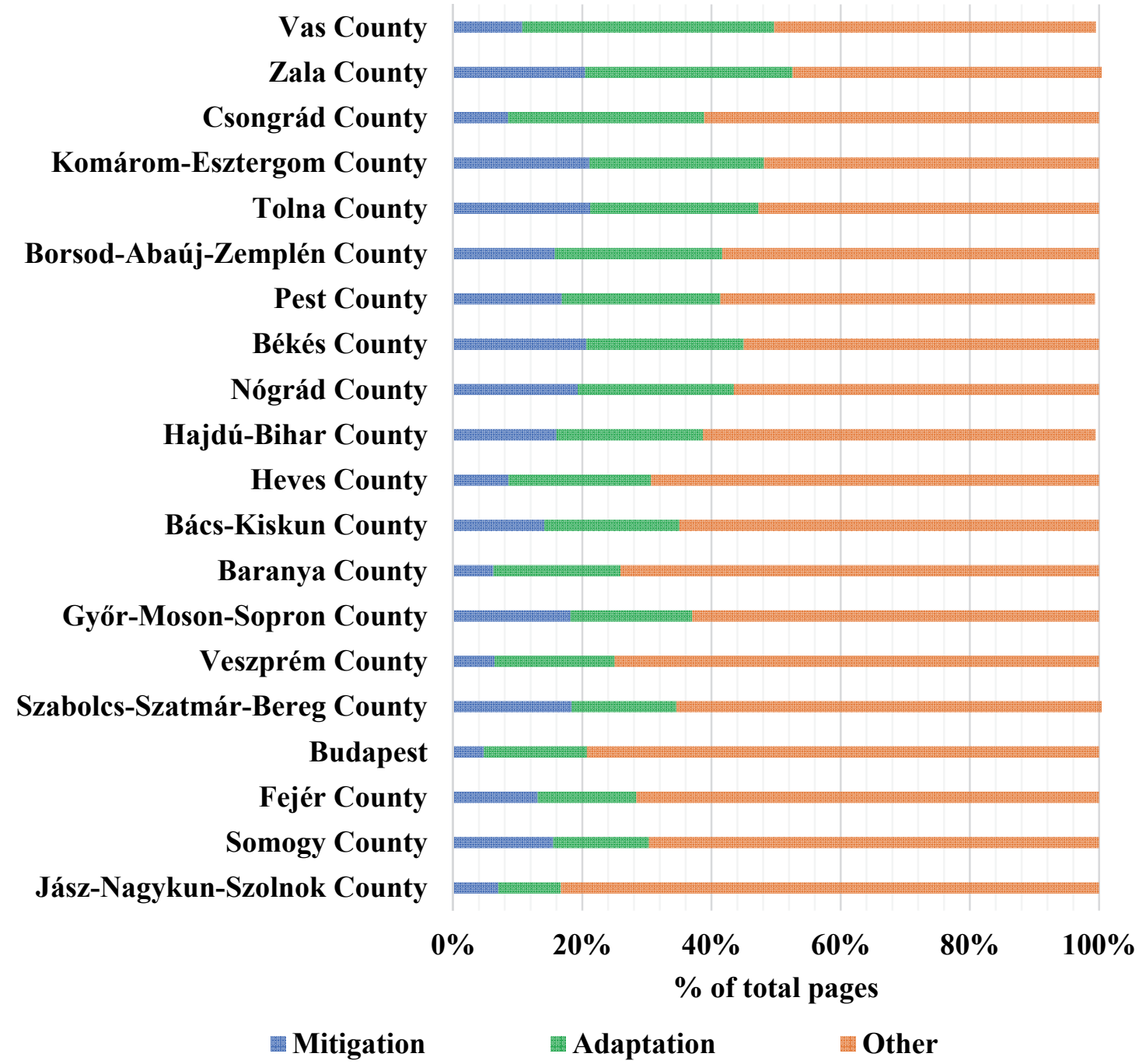

Fig. 7. Relative share of adaptation- and mitigation-oriented contents in the strategies. 
There are 19 county seats on LAU-1 level in Hungary. Out of the 19 cities, $63 \%$ have accepted some type of climate-related strategic or planning document. These documents were involved into the in-depth evaluation process considering the same questionnaire as in case of the counties and the capital. Two main types of documents can be found on this level, one of them is urban climate strategy, the other one is Sustainable Energy and Climate Plan (SECAP). 62\% of the county seats have SECAPs and the other $38 \%$ goes for the urban climate strategy. According to the year of the document developments it can be seen, that the oldest and still existing one was accepted in 2007, that is the urban climate strategy of Tatabánya. This county seat is a founding member city of the Climate-friendly Municipality Association and was among the first three cities in Hungary which worked out urban climate strategy. The latest climate strategy, that belongs to the county seat of Miskolc, was accepted in 2017. The 8 SECAPs has been developed between 2017 and 2019. Only 23\% of the evaluated documents have some existing history in the form of a planning document that is related to climate approach. A bit more than half of the examined documents includes paragraphs or chapters that are dealing with some general climate-related outlook on global, regional, or local level. It puts the climate change approach into context and provides a good background for easier understanding for the reader.

The absolute numbers of area-specific impacts are shown in the Fig. 8. All of the three types so the observed changes, the present impacts and the future projections are well represented in the examined documents. The most popular were the projection for the future. These information can be descriptive enough for decision makers or local residents as well.

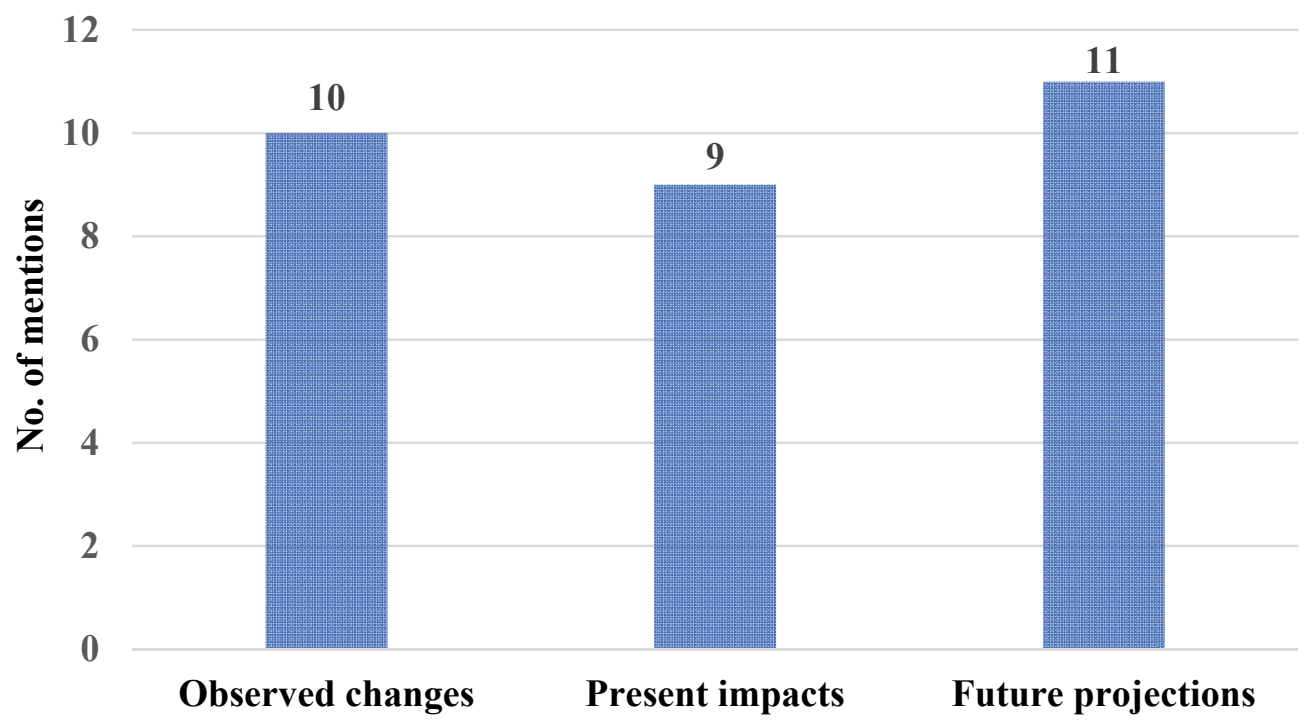

Fig. 8. Absolute number of mentions of area-specific impacts based on identified local characteristics (county seats). 
There are mentioned a wide range of climate-related impacts in the evaluated county seat documents, as can be seen in Fig. 9. The three most significant impacts are the temperature increase, the changing of the precipitation patterns and floods. Droughts, floods, forest fires belong to the next group based on the number of mentions. On the county seat level, the emphasis of local features may justify this diversity.

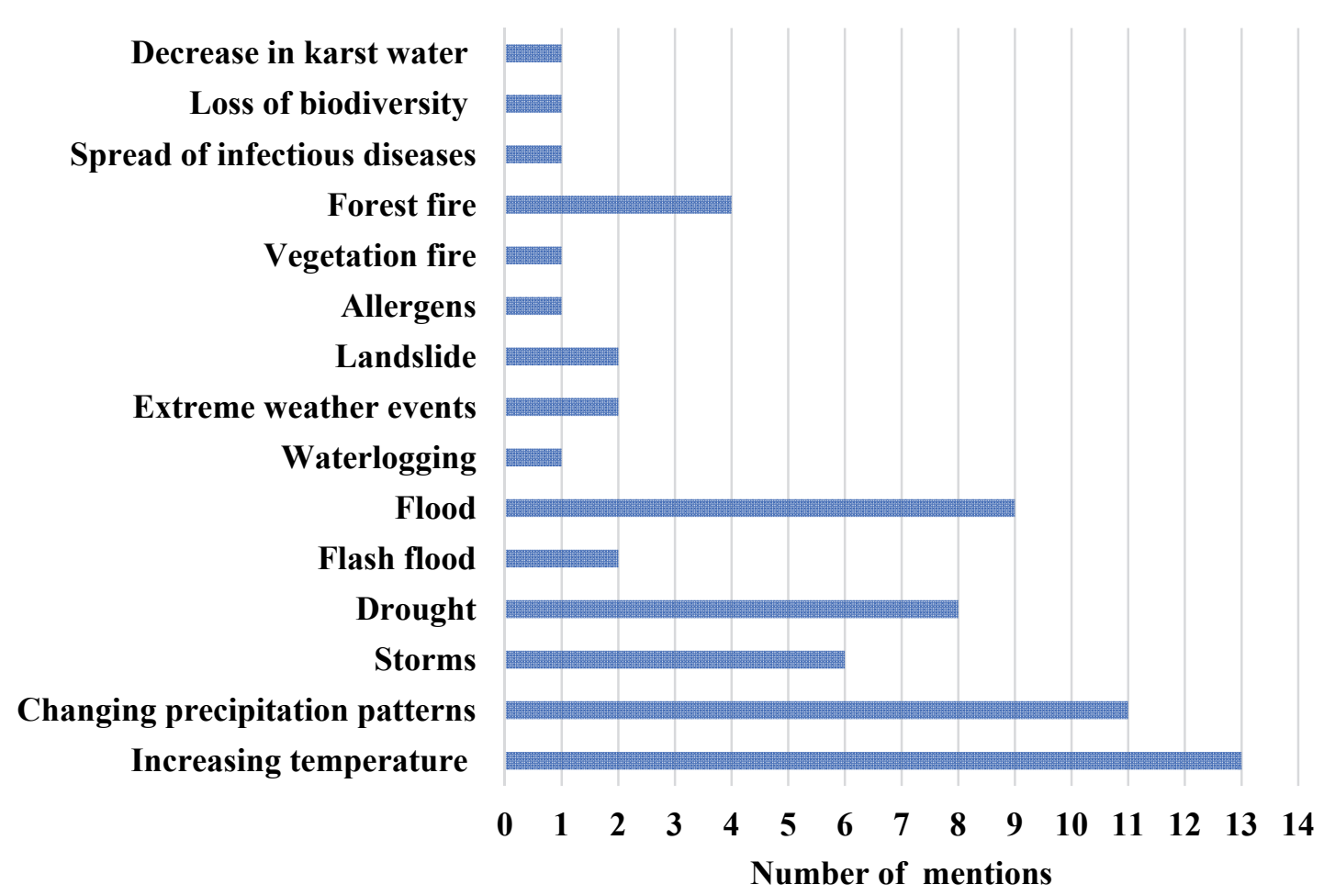

Fig. 9. Total number of mentions of climate-related impacts (county seats).

As was mentioned previously, according to the methodology, the next step is to check and analyze the consistency of the evaluated documents considering climate-related impacts and dedicated actions. Table 2 shows the results of this evaluation in case of county seats with SECAPs. There is not any action without impact. The significant proportion of the non-defined category is apparent. The existence or the lack of adaptation aims is independent of the date of the document development or assessment. Due to the requirements of the Covenant of Mayors for SECAPs, it is necessary to deal with the strengths and weaknesses of a territory, develop risk and vulnerability assessments that can allow convenient adaptation strategy development that can be converted into SECAP's actions.

The latest climate strategy was accepted in 2017 by the representative body of the municipality of Miskolc. However, not that document shows the best interrelations concerning climate-related impacts and adaptation actions. The 
best results, according to the consistency evaluation, can be seen related to the county seat of Eger that is shown in Table 3. This document was developed in 2012. The lack of knowledge transfer can be seen related to other cities.

Table 2. Climate-related impacts and dedicated actions in county seat SECAPs

\begin{tabular}{|c|c|c|c|c|c|c|c|c|c|}
\hline & & Debrecen & Dunaújváros & Kaposvár & Salgótarján & Szeged & Szolnok & Veszprém & Zalaegerszeg \\
\hline \multicolumn{10}{|l|}{ Increasing temperature } \\
\hline \multicolumn{2}{|l|}{ Changing precipitation patterns } & & $\mathrm{N} / \mathrm{D}$ & & & & & & \\
\hline \multicolumn{2}{|l|}{ Storms } & $\mathrm{N} / \mathrm{D}$ & & $\mathrm{N} / \mathrm{D}$ & $\mathrm{N} / \mathrm{D}$ & & & & $\mathrm{N} / \mathrm{D}$ \\
\hline \multicolumn{2}{|l|}{ Drought } & & & & $\mathrm{N} / \mathrm{D}$ & & & & $\mathrm{N} / \mathrm{D}$ \\
\hline \multicolumn{2}{|l|}{ Flash flood } & $\mathrm{N} / \mathrm{D}$ & $\mathrm{N} / \mathrm{D}$ & & & $\mathrm{N} / \mathrm{D}$ & $\mathrm{N} / \mathrm{D}$ & $\mathrm{N} / \mathrm{D}$ & $\mathrm{N} / \mathrm{D}$ \\
\hline \multicolumn{2}{|l|}{ Flood } & & & & & & & & $\mathrm{N} / \mathrm{D}$ \\
\hline \multicolumn{2}{|l|}{ Waterlogging } & & $\mathrm{N} / \mathrm{D}$ & $\mathrm{N} / \mathrm{D}$ & $\mathrm{N} / \mathrm{D}$ & $\mathrm{N} / \mathrm{D}$ & $\mathrm{N} / \mathrm{D}$ & $\mathrm{N} / \mathrm{D}$ & $\mathrm{N} / \mathrm{D}$ \\
\hline \multicolumn{2}{|l|}{ Extreme weather events } & $\mathrm{N} / \mathrm{D}$ & $\mathrm{N} / \mathrm{D}$ & $\mathrm{N} / \mathrm{D}$ & $\mathrm{N} / \mathrm{D}$ & $\mathrm{N} / \mathrm{D}$ & & $\mathrm{N} / \mathrm{D}$ & $\mathrm{N} / \mathrm{D}$ \\
\hline \multicolumn{2}{|l|}{ Landslide } & $\mathrm{N} / \mathrm{D}$ & & $\mathrm{N} / \mathrm{D}$ & $\mathrm{N} / \mathrm{D}$ & $\mathrm{N} / \mathrm{D}$ & $\mathrm{N} / \mathrm{D}$ & & $\mathrm{N} / \mathrm{D}$ \\
\hline \multicolumn{2}{|l|}{ Allergens } & $\mathrm{N} / \mathrm{D}$ & & $\mathrm{N} / \mathrm{D}$ & $\mathrm{N} / \mathrm{D}$ & $\mathrm{N} / \mathrm{D}$ & $\mathrm{N} / \mathrm{D}$ & $\mathrm{N} / \mathrm{D}$ & $\mathrm{N} / \mathrm{D}$ \\
\hline \multicolumn{2}{|l|}{ Vegetation fire } & $\mathrm{N} / \mathrm{D}$ & $\mathrm{N} / \mathrm{D}$ & $\mathrm{N} / \mathrm{D}$ & $\mathrm{N} / \mathrm{D}$ & $\mathrm{N} / \mathrm{D}$ & & $\mathrm{N} / \mathrm{D}$ & $\mathrm{N} / \mathrm{D}$ \\
\hline \multicolumn{2}{|l|}{ Forest fire } & $\mathrm{N} / \mathrm{D}$ & $\mathrm{N} / \mathrm{D}$ & N/D & $\mathrm{N} / \mathrm{D}$ & $\mathrm{N} / \mathrm{D}$ & $\mathrm{N} / \mathrm{D}$ & $\mathrm{N} / \mathrm{D}$ & $\mathrm{N} / \mathrm{D}$ \\
\hline \multicolumn{2}{|l|}{ Spread of infectious diseases } & $\mathrm{N} / \mathrm{D}$ & & $\mathrm{N} / \mathrm{D}$ & $\mathrm{N} / \mathrm{D}$ & $\mathrm{N} / \mathrm{D}$ & $\mathrm{N} / \mathrm{D}$ & $\mathrm{N} / \mathrm{D}$ & $\mathrm{N} / \mathrm{D}$ \\
\hline \multicolumn{2}{|l|}{ Loss of biodiversity } & $\mathrm{N} / \mathrm{D}$ & $\mathrm{N} / \mathrm{D}$ & $\mathrm{N} / \mathrm{D}$ & $\mathrm{N} / \mathrm{D}$ & $\mathrm{N} / \mathrm{D}$ & $\mathrm{N} / \mathrm{D}$ & $\mathrm{N} / \mathrm{D}$ & \\
\hline \multicolumn{2}{|l|}{ Decrease in karst water } & $\mathrm{N} / \mathrm{D}$ & $\mathrm{N} / \mathrm{D}$ & $\mathrm{N} / \mathrm{D}$ & $\mathrm{N} / \mathrm{D}$ & $\mathrm{N} / \mathrm{D}$ & $\mathrm{N} / \mathrm{D}$ & $\mathrm{N} / \mathrm{D}$ & $\mathrm{N} / \mathrm{D}$ \\
\hline \multirow[t]{4}{*}{$\mathrm{N} / \mathrm{D}$} & & non-def & ined & & & & & & \\
\hline & & pact and & $\operatorname{action}(\mathrm{s})$ & & & & & & \\
\hline & actic & $\mathrm{n}(\mathrm{s})$ with & out impact & & & & & & \\
\hline & imp & ct with & it $\operatorname{action}(\mathrm{s})$ & & & & & & \\
\hline
\end{tabular}

Table 3. Climate-related impacts and dedicated actions in county seat climate strategies

\begin{tabular}{|c|c|c|c|c|c|c|}
\hline \multirow{2}{*}{\multicolumn{2}{|c|}{ Increasing temperature }} & Eger & Miskolc & Szekszárd & Szombathely & Tatabánya \\
\hline & & & & & & \\
\hline \multicolumn{7}{|c|}{ Changing precipitation patterns } \\
\hline \multicolumn{2}{|l|}{ Storms } & & $\mathrm{N} / \mathrm{D}$ & & N/D & $\mathrm{N} / \mathrm{D}$ \\
\hline \multicolumn{2}{|l|}{ Drought } & & & $\mathrm{N} / \mathrm{D}$ & & $\mathrm{N} / \mathrm{D}$ \\
\hline \multicolumn{2}{|l|}{ Flash flood } & N/D & N/D & N/D & N/D & N/D \\
\hline \multicolumn{2}{|l|}{ Flood } & & & $\mathrm{N} / \mathrm{D}$ & & $\mathrm{N} / \mathrm{D}$ \\
\hline \multicolumn{2}{|l|}{ Waterlogging } & $\mathrm{N} / \mathrm{D}$ & $\mathrm{N} / \mathrm{D}$ & $\mathrm{N} / \mathrm{D}$ & $\mathrm{N} / \mathrm{D}$ & $\mathrm{N} / \mathrm{D}$ \\
\hline \multicolumn{2}{|c|}{ Extreme weather events } & & $\mathrm{N} / \mathrm{D}$ & $\mathrm{N} / \mathrm{D}$ & $\mathrm{N} / \mathrm{D}$ & $\mathrm{N} / \mathrm{D}$ \\
\hline \multicolumn{2}{|l|}{ Landslide } & $\mathrm{N} / \mathrm{D}$ & N/D & $\mathrm{N} / \mathrm{D}$ & $\mathrm{N} / \mathrm{D}$ & $\mathrm{N} / \mathrm{D}$ \\
\hline \multicolumn{2}{|l|}{ Allergens } & $\mathrm{N} / \mathrm{D}$ & $\mathrm{N} / \mathrm{D}$ & $\mathrm{N} / \mathrm{D}$ & $\mathrm{N} / \mathrm{D}$ & $\mathrm{N} / \mathrm{D}$ \\
\hline \multicolumn{2}{|c|}{ Vegetation fire } & $\mathrm{N} / \mathrm{D}$ & N/D & $\mathrm{N} / \mathrm{D}$ & $\mathrm{N} / \mathrm{D}$ & $\mathrm{N} / \mathrm{D}$ \\
\hline \multicolumn{2}{|l|}{ Forest fire } & & $\mathrm{N} / \mathrm{D}$ & & N/D & \\
\hline \multicolumn{2}{|c|}{ Spread of infectious diseases } & $\mathrm{N} / \mathrm{D}$ & $\mathrm{N} / \mathrm{D}$ & $\mathrm{N} / \mathrm{D}$ & $\mathrm{N} / \mathrm{D}$ & $\mathrm{N} / \mathrm{D}$ \\
\hline \multicolumn{2}{|c|}{ Loss of biodiversity } & $\mathrm{N} / \mathrm{D}$ & $\mathrm{N} / \mathrm{D}$ & $\mathrm{N} / \mathrm{D}$ & N/D & $\mathrm{N} / \mathrm{D}$ \\
\hline \multicolumn{2}{|c|}{ Decrease in karst water } & $\mathrm{N} / \mathrm{D}$ & & $\mathrm{N} / \mathrm{D}$ & $\mathrm{N} / \mathrm{D}$ & $\mathrm{N} / \mathrm{D}$ \\
\hline \multirow[t]{3}{*}{$\mathrm{N} / \mathrm{D}$} & \multicolumn{2}{|c|}{ non-defined } & & & & \\
\hline & \multicolumn{2}{|c|}{ impact and action(s) } & & & & \\
\hline & \multicolumn{2}{|c|}{ impact without action(s) } & & & & \\
\hline
\end{tabular}


Altogether 3 examined document deals with the vulnerable social groups despite the importance of this aspect in adaptation planning and concerning adaptation pathways. These documents mention as vulnerable social groups, the infants and younger children, the elderly population, and people with chronic cardiovascular disease.

Almost half of the evaluated documents do not define any sector related to adaptation aims (see Fig. 10). The most emphasized sector among the adaptation aims is water management due to its unpredictability and importance according to living standards, quality of life, and sustainability. The same importance was given to the following four as agriculture, health, energy industry, and urban planning. These are followed by transport, tourism, nature conservation, and finally, waste and disaster management can be found in the chart.

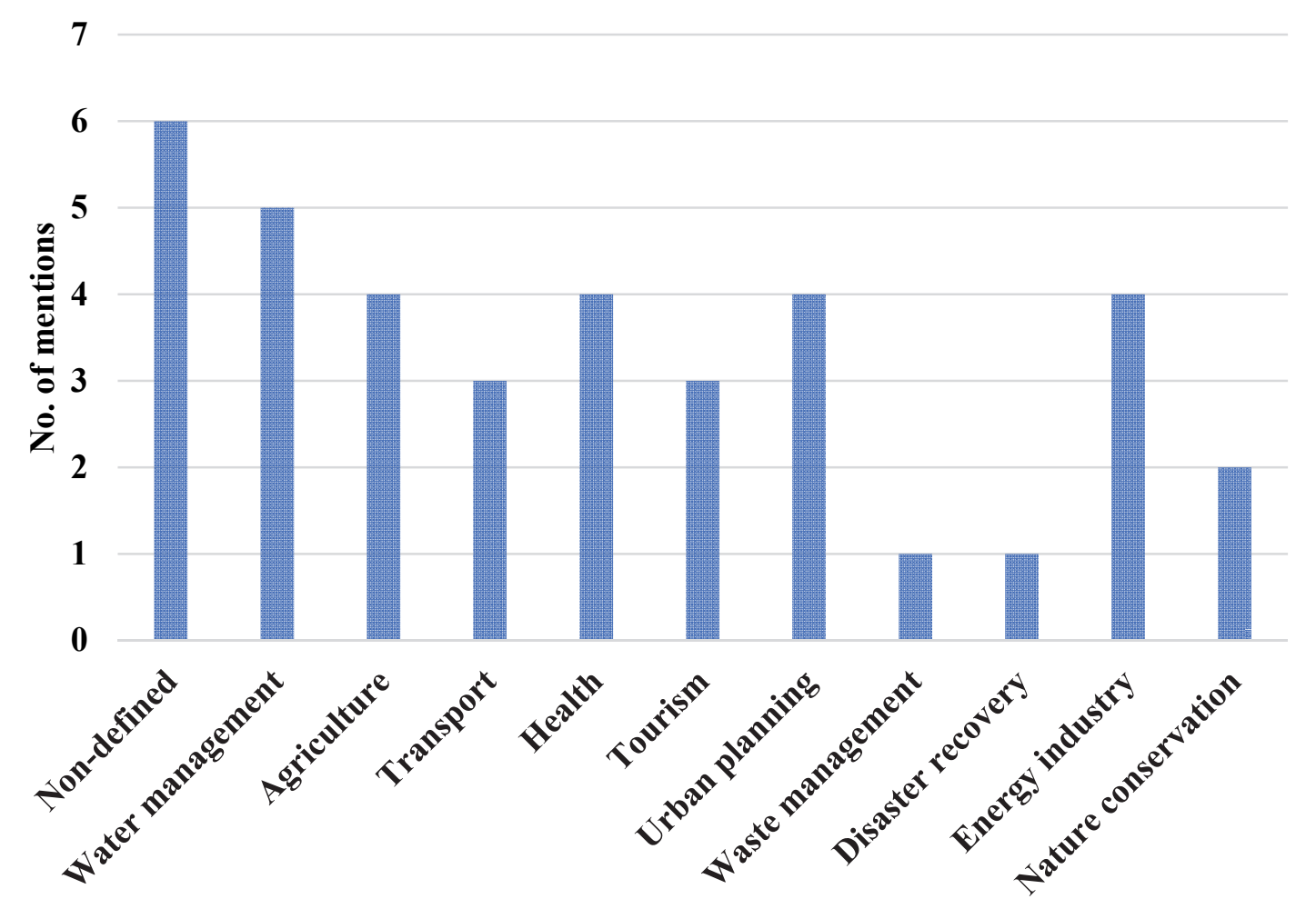

Fig. 10. Total number of mentions of sectors among the aims of examined county seat level documents.

Based on the evaluation of the 13 climate-related strategic documents on the county seat level, it can be seen that in the case of $69 \%$ of the examined documents, the overall lack of adaptation aims can be stated. Thus, only $31 \%$ of the documents discuss some details according to the adaptation aims. 
Fig. 11 gives an overview of the adaptation actions and shows the high percentage of the non-defined category. The core actions belong to the technical solution or awareness-raising, followed by education and policy-related actions.

Only $31 \%$ of the evaluated documents gives at least a general overview, according to monitoring. In two cases, indicators and timeframe were also mentioned as necessary parts of the monitoring phase. None of the evaluated document mentions the importance and meaning of partnership. Only four cases deal with an open discussion about the planned document with different local actors and stakeholders.

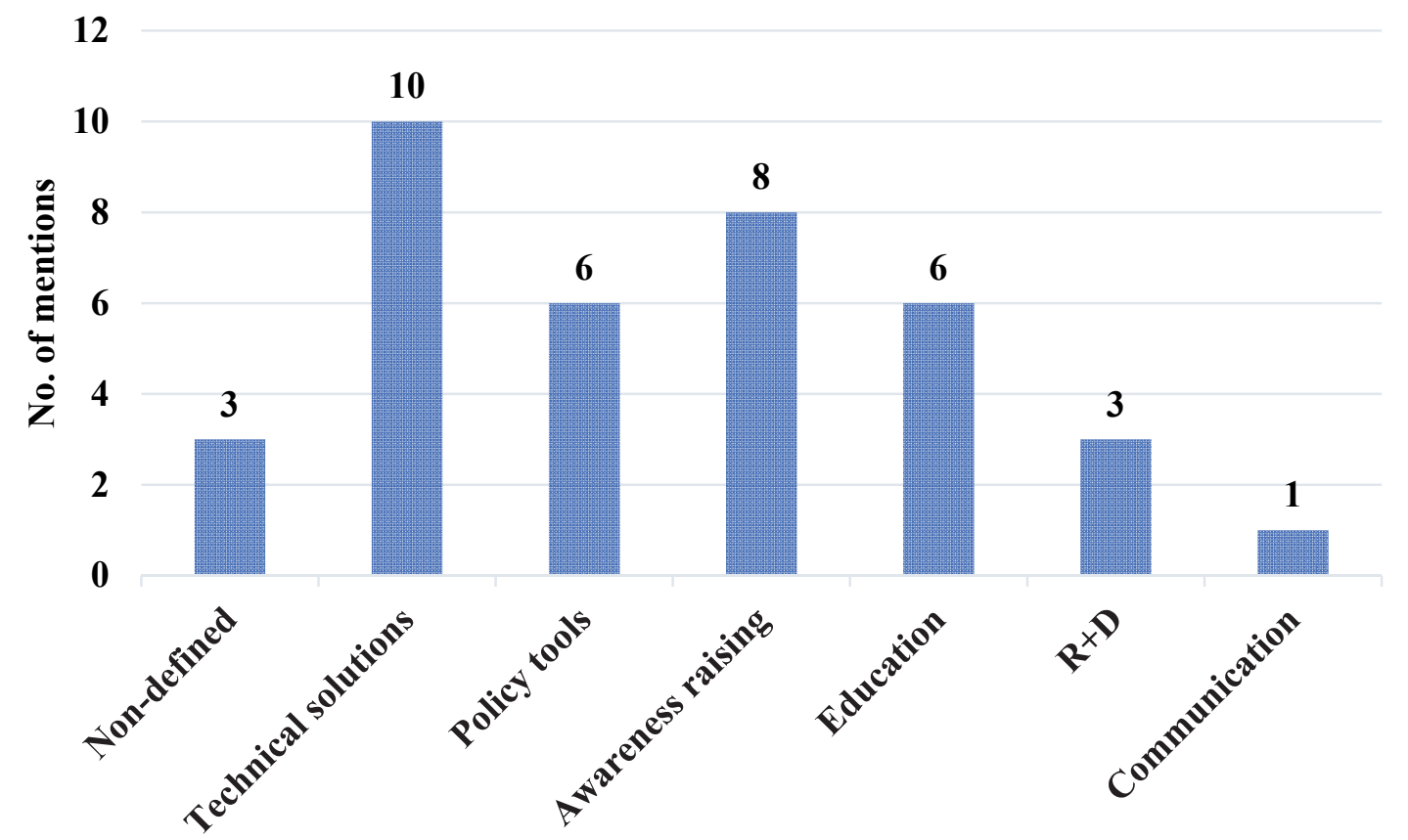

Fig. 11. Total number of mentions of adaptation actions among the aims of examined county seat level documents.

According to Fig. 12 on the county seat level, the representation of the relative share of adaptation and mitigation-oriented content can be seen. Clearly, the least represented approach is an adaptation to climate change despite the importance of this kind of activities, interventions, and tools in order to support the transition towards sustainable regional development. The most adaptationfocused documents were formulated in Szeged and Dunaújváros, that is followed in the row by Tatabánya, Szekszárd, Eger, Salgótarján. There is a complete lack of adaptation content that can be found in the case of Debrecen. 


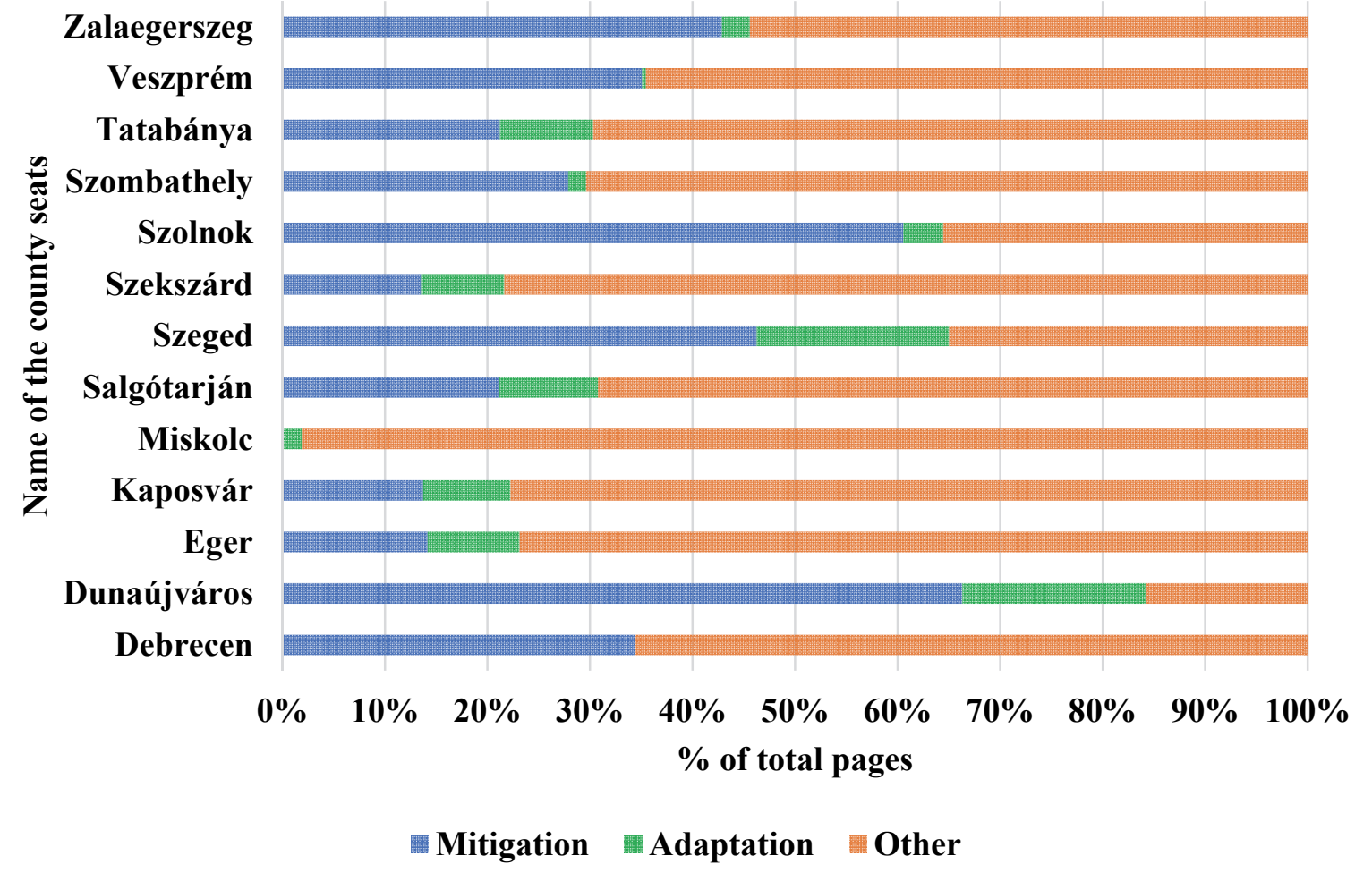

Fig. 12. Relative share of adaptation- and mitigation-oriented content in the examined documents.

\section{Conclusion}

The Hungarian counties made an unquestionably enormous effort by developing their climate change strategies during the past years. Content analysis of documents revealed their complexity and heterogeneity; however, a strict methodological guideline developed by the Alliance of Climate-friendly Settlements were available. The survey applied for identifying key strengths and weaknesses of climate change strategies on the county level was a crucial part of this process and entailed to define several further recommendations. Firstly, it shall be emphasized that county-level climate change strategies cover all of the relevant climate-related impacts regarding both the present and future. Nevertheless, after a detailed analysis of actions, it can be stated that best practices regarding the planning phase in terms of impacts-actions pairs are severely limited, since numerous climate strategies can be found in which relevant impacts were mentioned without any related actions or vice versa. Vulnerable social groups are also defined and introduced by the analyzed documents. However, it is worth mentioning that the inclusiveness of vulnerable people is weak: outdoor workers, people with disabilities, and poor people have not been taken into consideration in an emphasized way regardless of their vulnerability to changing climatic patterns. 
A further weakness of strategy-making processes can be characterized by paying attention to the outcomes of content analysis regarding the number of mentions of different sectors through the adaptation-oriented goals. From the planning perspective, diversification of tools regarding the implementation of actions is crucial to enhance the effectiveness of a given strategy. The majority of climate strategies include technical solutions, policy tools, and awarenessraising projects, with much less attention to education, financial tools, and $\mathrm{R}+\mathrm{D}$ actions. Besides the lack of given types of actions, some deficiencies concerning the monitoring phase have also been characterized: a complete lack of contents regarding priorities between aims and goals and of responsibilities during the implementation phase. Last but not least, the share of adaptation-related content varies significantly from 39\% (Vas County) to 10\% (Jász-Nagykun-Szolnok County) that represents a significant heterogeneity in terms of the relative importance of adaptation issues in a given strategy. It cannot be stated clearly that lengthy adaptation contents are related to an improved quality of strategies; however, it shall be declared that paying more attention to climate adaptation issues is in parallel with EU-level activities nowadays and the near future.

Considering climate planning documents on the county seat (LAU-1) level, more diverse and heterogeneous results can be seen compared to the county level. This heterogeneity of adaptation issues can be found both in the evaluated climate change-related strategies and SECAPs in the case of the Hungarian county seats. Based on our in-depth evaluation of this level, according to adaptation in several cases, the lack of the appropriate planning document is the most striking. This diversity visible, for example, in the case of climate-related impacts. On county seat level, the planned adaptation aims, related sectors, and actions are significantly underrepresented in the evaluated documents. The monitoring phase can also be seen as a crucial point in further developments for an adaptive future on different spatial levels.

Acknowledgements: The research reported in this paper was supported by the Higher Education Excellence Program of the Ministry of Human Capacities in the frame of the Water sciences \& Disaster Prevention research area of the Budapest University of Technology and Economics (BME FIKP-VÍZ).

\section{References}

Bartholy, J., Radics, K., and Bohoczky, F., 2003: Present state of wind energy utilisation in Hungary: Policy, wind climate, and modelling studies. Renew. Sustain. Energy Rev. 7, 175-186. https://doi.org/10.1016/S1364-0321(03)00003-0

Bartholy, J., Pongrácz, R., and Gelybó, G.Y., 2007: Regional climate change expected in Hungary for 2071-2100. Appl. Ecol. Environ. Res. 5, 1-17. https://doi.org/10.15666/aeer/0501 001017

Bartholy, J., Pongracz, R., Torma, C., Pieczka, I., Kardos, P., and Hunyady, A., 2009: Analysis of regional climate change modelling experiments for the Carpathian Basin. Int. J. Glob. Warming 1, 238-252. https://doi.org/10.1504/IJGW.2009.027092 
Bellinson, $R$. and Chu, E., 2019: Learning pathways and the governance of innovations in urban climate change resilience and adaptation. J. Environ. Policy Planning, 21, 76-89. https://doi.org/10.1080/1523908X.2018.1493916

Berkhout, F., Bouwer, L.M., Bayer, J., Bouzid, M., Cabeza, M., Hanger, S., Hof, A., Hunter, P., Meller, L., Patt, A., Pfluger, B., Rayner, T., Reichardt, K., and van Teeffelen, A., 2015: European policy responses to climate change: progress on mainstreaming emissions reduction and adaptation. Reg. Environ. Change 15, 949-959. https://doi.org/10.1007/s10113-015-0801-6

Blanka, V., Mezosi, G., and Meyer, B., 2013: Projected changes in the drought hazard in Hungary due to climate change. Idöjárás 117, 219-237.

Bobvos, J., Fazekas, B., and Páldy, A., 2015: Assessment of heat-related mortality in budapest from 2000 to 2010 by different indicators. Időjárás, 119, 143-158.

Buzási, A., 2014: Will Budapest be a climate-resilient city? - Adaptation and mitigation challenges and opportunities in development plans of Budapest. Eur. J.Sustain. Develop. 3, 277-288. https://doi.org/10.14207/ejsd.2014.v3n4p277

Castán Broto, V., 2017: Urban Governance and the Politics of Climate change. World Develop. 93, 1-15. https://doi.org/10.1016/j.worlddev.2016.12.031

European Commission, 2011: A Roadmap for moving to a competitive low carbon economy in 2050.

Csete, M. and Horváth, L., 2012: Sustainability and green development in urban policies and strategies. Appl. Ecol. Environ. Res. 10, 185-194. https://doi.org/10.15666/aeer/1002_185194

Csete, M., Pálvölgyi, T., and Szendrö, G., 2013: Assessment of climate change vulnerability of tourism in Hungary. Reg. Environ. Change 13, 1043-1057. https://doi.org/10.1007/s10113-013-0417-7

Csete, M. and Szécsi, N., 2015: The role of tourism management in adaptation to climate change - a study of a European inland area with a diversified tourism supply. J. Sustain. Tourism 23, 477-496. https://doi.org/10.1080/09669582.2014.969735

Csete, M. and Buzási, A., 2016: Climate-oriented assessment of main street design and development in Budapest. J. Environ. Engineer. Landscape Manage. 24, 258-268. https://doi.org/10.3846/16486897.2016.1185431

Czakó, $V$., 2013: Drowning the suburb: settlement planning and climate change adaptation in a Hungarian metropolitan area. Urban Res. Practice 6, 95-109. https://doi.org/10.1080/17535069.2012.762221

Eckersley, P., England, K., and Ferry, L., 2018: Sustainable development in cities: collaborating to improve urban climate resilience and develop the business case for adaptation. Publ. Money Management, 38, 335-344. https://doi.org/10.1080/09540962.2018.1477642

Gaál, M., Quiroga, S., and Fernandez-Haddad, Z., 2014: Potential impacts of climate change on agricultural land use suitability of the Hungarian counties. Reg. Environ. Change 14, 597-610. https://doi.org/10.1007/s10113-013-0518-3

Heidrich, O., Dawson, R.J., Reckien, D., and Walsh, C.L., 2013: Assessment of the climate preparedness of 30 urban areas in the UK. Climatic Change, 120, 771-784. https://doi.org/10.1007/s10584-013-0846-9

Heidrich, O., Reckien, D., Olazabal, M., Foley, A., Salvia, M., de Gregorio Hurtado, S., Orru, H., Flacke, J., Geneletti, D., Pietrapertosa, F., Hamann, J.J.P., Tiwary, A., Feliu, E., and Dawson, R.J., 2016: National climate policies across Europe and their impacts on cities strategies. $J$. Environ. Manage. 168, 36-45. https://doi.org/10.1016/j.jenvman.2015.11.043

Hlásny, T., Mátyás, C., Seidl, R., Kulla, L., Merganičová, K., Trombik, J., Dobor, L., Barcza, Z., and Konôpka, B., 2014: Climate change increases the drought risk in Central European forests: What are the options for adaptation? Forestry J. 60, 5-18. https://doi.org/10.2478/forj-2014-0001

Hrabovszky-Horváth, S., Pálvölgyi, T., Csoknyai, T., and Talamon, A., 2013: Generalized residential building typology for urban climate change mitigation and adaptation strategies: The case of Hungary. Energy and Build. 62, 475-485. https://doi.org/10.1016/j.enbuild.2013.03.011

Hunt, A and Watkiss, P., 2011: Climate change impacts and adaptation in cities: A review of the literature. Climatic Change 104, 13-49. https://doi.org/10.1007/s10584-010-9975-6

Jolánkai, M. and Birkás, M., 2007: Global climate change impacts on crop production in Hungary. Agric. Conspectus Scientificus 72, 17-20.

Kántor, N., Chen, L., and Gál, C. V., 2018: Human-biometeorological significance of shading in urban public spaces-Summertime measurements in Pécs, Hungary. Landscape Urban Plann. 170, 241-255. https://doi.org/10.1016/j.landurbplan.2017.09.030 
Kern, K., 2019: Cities as leaders in EU multilevel climate governance: embedded upscaling of local experiments in Europe. Environ. Politics 28, 125-145.

https://doi.org/10.1080/09644016.2019.1521979

Kis, A., Pongrácz, R., and Bartholy, J., 2017: Multi-model analysis of regional dry and wet conditions for the Carpathian Region. Int. J Climatol 37, 4543-4560. https://doi.org/10.1002/joc.5104

Kovács, A., and Unger, J., 2014: Analysis of the tourism climatic conditions in Hungary concerning the subjective thermal sensation characteristics of the south-hungarian resident, Acta Climatologics et chorologica 47-48, 77-84.

Kovács, A., Németh, Á., Unger, J., and Kántor, N., 2017: Tourism climatic conditions of Hungary present situation and assessment of future changes Attila. Idöjárás 121, 79-99.

Krüzselyi, I., Bartholy, J., Horányi, A., Pieczka, I., Pongrácz, R., Szabó, P., Szépszó, G., and Torma, $C ., 2011$ : The future climate characteristics of the Carpathian Basin based on a regional climate model mini-ensemble. Adv. Sci. Res. 6, 69-73. https://doi.org/10.5194/asr-6-69-2011

Li, S., Juhász-Horváth, L., Harrison, P.A., Pintér, L., and Rounsevell, M.D.A., 2017a: Relating farmer's perceptions of climate change risk to adaptation behaviour in Hungary. $J$. Environ.Management, 185, 21-30. https://doi.org/10.1016/j.jenvman.2016.10.051

Li, S., Juhász-Horváth, L., Pedde, S., Pintér, L., Rounsevell, M.D.A., and Harrison, P.A., 2017b: Integrated modelling of urban spatial development under uncertain climate futures: A case study in Hungary. Environ. Model. Software 96, 251-264. https://doi.org/10.1016/j.envsoft.2017.07.005

Li, S., Juhász-Horváth, L., Pintér, L., Rounsevell, M.D.A., and Harrison, P.A., 2018: Modelling regional cropping patterns under scenarios of climate and socio-economic change in Hungary. Sci. Total Environ. 622-623, 1611-1620. https://doi.org/10.1016/j.scitotenv.2017.10.038

Lóczy, D., 2010: Flood hazard in Hungary: A re-assessment. Centr. Eur. J. Geosci. 2, 537-547. https://doi.org/10.2478/v10085-010-0029-0

Malatinszky, Á., Ádám, S., Falusi, E., Saláta, D., and Penksza, K., 2013: Climate change related land use problems in protected wetlands: A study in a seriously affected Hungarian area. Climatic Change 118, 671-682. https://doi.org/10.1007/s10584-012-0689-9

Mendizabal, M., Heidrich, O., Feliu, E., García-Blanco, G., and Mendizabal, A., 2018: Stimulating urban transition and transformation to achieve sustainable and resilient cities. Renew. Sustain. Energy Rev. 94, 410-418. https://doi.org/10.1016/j.rser.2018.06.003

Mezösi, G., Meyer, B.C., Loibl, W., Aubrecht, C., Csorba, P., and Bata, T., 2013: Assessment of regional climate change impacts on Hungarian landscapes. Reg. Environ. Change 13, 797-811. https://doi.org/10.1007/s10113-012-0326-1

Mezösi, G., Bata, T., Meyer, B.C., Blanka, V., and Ladányi, Z., 2014: Climate Change Impacts on Environmental Hazards on the Great Hungarian Plain, Carpathian Basin. Int. J. Disaster Risk Sci. 5, 136-146. https://doi.org/10.1007/s13753-014-0016-3

Millard-Ball, A., 2013: The Limits to Planning: Causal Impacts of City Climate Action Plans. J. Planning Educ. Res. 33, 5-19. https://doi.org/10.1177/0739456X12449742

Páldy, A., Bobvos, J., Vámos, A., Kovats, R.S., and Hajat, S., 2005: The Effect of Temperature and Heat Waves on Daily Mortality in Budapest, Hungary, 1970 - 2000, In: (eds. Kirch, W., Bertollini, R., and Menne, B.) Extreme Weather Events and Public Health Responses. Springer Berlin Heidelberg, Berlin, Heidelberg, 99-107. https://doi.org/10.1007/3-540-28862-7_10

Páldy, A., and Bobvos, J., 2010: Health Impacts of Heat Waves of 2007 in Hungary -- Background and Experiences, In: Global Warming: Engineering Solutions (eds. Dincer, I., Hepbasli, A., Midilli, A., and Karakoc, T.H.). Springer US, Boston, MA, 629-642. https://doi.org/10.1007/978-1-4419-1017-2_44

Pietrapertosa, F., Khokhlov, V., Salvia, M., and Cosmi, C., 2018: Climate change adaptation policies and plans: A survey in 11 South East European countries. Renew. Sustain. Energy Rev. 81, 3041-3050. https://doi.org/10.1016/j.rser.2017.06.116

Pongrácz, R., Bartholy, J., and Bartha, E.B., 2013: Analysis of projected changes in the occurrence of heat waves in Hungary. Adv. Geosci. 35, 115-122. https://doi.org/10.5194/adgeo-35-115-2013

Pongrácz, R., Bartholy, J., and Kis, A., 2014: Estimation of future precipitation conditions for Hungary with special focus on dry periods. Időjárás 118, 305-321. 
Reckien, D., Flacke, J., Dawson, R.J., Heidrich, O., Olazabal, M., Foley, A., Hamann, J.J.P., Orru, H., Salvia, M., de Gregorio Hurtado, S., Geneletti, D., and Pietrapertosa, F., 2014: Climate change response in Europe: What's the reality? Analysis of adaptation and mitigation plans from 200 urban areas in 11 countries. Climatic Change, 122, 331-340. https://doi.org/10.1007/s10584-013-0989-8

Reckien, D., Flacke, J., Olazabal, M., and Heidrich, O., 2015: The influence of drivers and barriers on urban adaptation and mitigation plans-an empirical analysis of European Cities. PLoS ONE 10, 121. https://doi.org/10.1371/journal.pone.0135597

Reckien, D., Salvia, M., Heidrich, O., Church, J.M., Pietrapertosa, F., De Gregorio-Hurtado, S., D’Alonzo, V., Foley, A., Simoes, S.G., Krkoška Lorencová, E., Orru, H., Orru, K., Wejs, A., Flacke, J., Olazabal, M., Geneletti, D., Feliu, E., Vasilie, S., Nador, C., Krook-Riekkola, A., Matosović, M., Fokaides, P.A., Ioannou, B.I., Flamos, A., Spyridaki, N.A., Balzan, M. V., Fülöp, O., Paspaldzhiev, I., Grafakos, S., and Dawson, R., 2018: How are cities planning to respond to climate change? Assessment of local climate plans from 885 cities in the EU-28. J. Cleaner Product 191, 207-219. https://doi.org/10.1016/j.jclepro.2018.03.220

Reckien, D., Salvia, M., Pietrapertosa, F., Simoes, S.G., Olazabal, M., De Gregorio Hurtado, S., Geneletti, D., Krkoška Lorencová, E., D’Alonzo, V., Krook-Riekkola, A., Fokaides, P.A., Ioannou, B.I., Foley, A., Orru, H., Orru, K., Wejs, A., Flacke, J., Church, J.M., Feliu, E., Vasilie, S., Nador, C., Matosović, M., Flamos, A., Spyridaki, N.A., Balzan, M. V., Fülöp, O., Grafakos, S., Paspaldzhiev, I., and Heidrich, O., 2019: Dedicated versus mainstreaming approaches in local climate plans in Europe. Renew. Sustain. Energy Rev. 112, 948-959. https://doi.org/10.1016/j.rser.2019.05.014

Rojas, R., Feyen, L., and Watkiss, P., 2013: Climate change and river floods in the European Union: Socio-economic consequences and the costs and benefits of adaptation. Glob. Environ. Change, 23, 1737-1751. https://doi.org/10.1016/j.gloenvcha.2013.08.006

Rosenzweig, C., Solecki, W., Hammer, S.A., and Mehrotra, S., 2010: Cities lead the way in climatechange action. Nature 467, 909-911. https://doi.org/10.1038/467909a

Sharifi, A. and Yamagata, Y., 2016: Principles and criteria for assessing urban energy resilience: A literature review. Renew. Sustain. Energy Rev. 60, 1654-1677.

https://doi.org/10.1016/j.rser.2016.03.028

Solymosi, N., Torma, C., Kern, A., Maróti-Agóts, Á., Barcza, Z., Könyves, L., Berke, O., and Reiczigel, $J ., 2010$ : Changing climate in Hungary and trends in the annual number of heat stress days. International J. Biometeorol. 54, 423-431. https://doi.org/10.1007/s00484-009-0293-5

Szabó, B., Vincze, E., and Czúcz, B., 2016: Flowering phenological changes in relation to climate change in Hungary. Int. J. Biometeorol. 60, 1347-1356. https://doi.org/10.1007/s00484-015$1128-1$

Szendrö, G., Csete, M., and Török, Á,, 2014: The sectoral adaptive capacity index of Hungarian road transport. Periodica Polytechnica Social Manage. Sci. 22, 99-106. https://doi.org/10.3311/PPso.7377

Szépszó, G., 2008: Regional change of climate extremes over Hungary based on different regional climate models of the PRUDENCE project. Idöjárás 112, 265-284.

Szlávik, J. and Csete, M., 2012: Climate and energy policy in Hungary. Energies 5, 494-517. https://doi.org/10.3390/en5020494

Tánczos, K. and Török, A., 2007: The linkage between climate change and energy consumption of hungary in the road transportation sector. Transport 22, 134-138. https://doi.org/10.3846/16484142.2007.9638111

Torma, C., Coppola, E., Giorgi, F., Bartholy, J., and Pongrácz, R., 2011: Validation of a highresolution version of the regional climate model RegCM3 over the Carpathian basin. J.Hydrometeorol. 12, 84-100. https://doi.org/10.1175/2010JHM1234.1

Törö, K., Bartholy, J., Pongrácz, R., Kis, Z., Keller, É., and Dunay, G., 2010: Evaluation of meteorological factors on sudden cardiovascular death. J. Forensic Legal Medic. 17, 236-242. https://doi.org/10.1016/j.jflm.2010.02.008

UNFCCC, 2015: Adoption of the Paris agreement.

Ürge-Vorsatz, D., Rosenzweig, C., Dawson, R.J., Sanchez Rodriguez, R., Bai, X., Salisu Barau, A., Seto, K.C., and Dhakal, S., 2018: Locking in positive climate responses in cities Adaptation- 
mitigation interdependencies. Nat. Climate Change 8, 174-185. https://doi.org/10.1038/s41558018-0100-6

Wamsler, C., Brink, E., and Rivera, C., 2013: Planning for climate change in urban areas: From theory to practice. J. Cleaner Product. 50, 68-81. https://doi.org/10.1016/j.jclepro.2012.12.008

Werners, S.E., Flachner, Z., Matczak, P., Falaleeva, M., and Leemans, R., 2009: Exploring earth system governance: A case study of floodplain management along the Tisza river in Hungary. Global Environmental Change, 19, 503-511. https://doi.org/10.1016/j.gloenvcha.2009.07.003

Zemankovics, M.H., 2012: Mitigation and adaptation to climate change in Hungary. J. Central Eur. Agricult. 13, 58-72. https://doi.org/10.5513/JCEA01/13.1.1015 